\title{
Articles
}

Central European Review of Economics \& Finance

Vol. 20, No. 4 (2017), pp. 5-15. D0I: 10.24136/ceref.2017.014

Jacek Jaworski $\mathbf{i}^{1}$

\section{AN ADVERTISING FEE IN A SYSTEM OF LOCAL FEES}

An advertising fee was introduced to the system of fees and local taxes, becoming a financial tool to shape the space and increase the budget revenues of local government units in Poland. This article is intended to describe the fee structure itself, determine its subjective and objective scope and discuss exemptions from advertising fees. Given that the text is a follow - up to an academic conference attended also by local government representatives, particular attention was paid to the practical evaluation of the risk and difficulties communes may face during the collection of advertising fees.

\section{JEL Classification Codes: M3, H71.}

Keywords: Advertising fee, Local fees.

\section{Introduction}

Local fees constitute a source of budget revenues and as such they have a real influence on the financial standing of local government units. The introduction of a new fee, called an advertising fee, to a system of local fees, seems desirable, at least with regard to the public finance. Enlarging the catalogue of fees by the legislator must be perceived as positive by members of local governments.

It is disputable how efficiently and effectively a local government may impose and collect fees, or within a broader context, how far it may go in its activities to raise money. It depends on the concept of the state and economy, system of fees and duties, and, finally, also on the financial standing of lo-

\footnotetext{
${ }^{1}$ Assistant Professor, PhD, Kardynal Stefan Wyszynski University in Warsaw; Legal Adviser in Warsaw.
} 
cal governments, including, in particular, a catalogue of tasks entrusted to them, concerning the participation in commonly collected public duties, going towards the state budget. This article concerns the possibility of imposing advertising fees under the Polish law, so when it refers to local government units, it refers only to the Polish local government units.

The amounts, which are to go towards local government budgets, must be paid by someone. In this context, the introduction of local advertising fees may be perceived not only as an element contributing to the increase of budget revenues, but mainly as a burden to budgets of advertisers. Advertising costs presently constitute one of the basic elements of fixed costs related to the reaching of a target recipient of a product or service. Such costs may be considered an investment, since it is expected that advertising will be a "leverage of trade". It is necessary to bear advertising costs for marketing to be effective as an element of running one's business as a means of communication between a consumer and a producer (Orżewski, 2012, p. 13).

Therefore, since advertising is indispensable and the advertising market seems to have considerable resources, then, from this perspective, advertising fees may be perceived as an attempt of a local government to use those resources.

The indicated complexity of the problem prevents explicit evaluation of the introduction of an advertising fee. In order to evaluate the scale of this phenomenon and its effects, not only law, but also statistics and economy should be considered. Nonetheless, advertising fees may be deemed a financial tool aimed at achieving statutory goals, other than the economic ones. It seems that such a goal, with regard to an advertising fee, is the landscape conservation within the framework of sustainable development and maintenance of spatial order. These are, indisputably, common (public) values, which may explain why the legislator chose to introduce the institution of advertising fees in the public law sphere.

Local fees, present in the Polish system, are provided for by the Act of 12 January 1991 on Taxes and Local Fees (Act on Taxes and Local Fees, 1991). The local fees include:

a) a market fee (Act on Taxes and Local Fees, 1991, Articles 15-16), which is collected from natural persons, legal persons and organisational units without legal personality, selling goods on markets; 
b) a dog fee, which is collected from natural persons who own dogs, including statutory exemptions;

c) a tourist fee (Act on Taxes and Local Fees, 1991, Article 17) (a so-called climate fee), which is collected for each commenced day of stay, from natural persons, staying for more than 24 hours, for tourist, holiday, or training purposes, in towns which offer favourable climatic conditions, landscape value, and conditions enabling people to stay there for such purposes and in towns located in the areas, which have been granted the status of health-resort protection areas, under the provisions of the Act of 28 July 2005 on Health Resort Medical Care, Health Resorts, Health Resort Protection Areas and Health Resort Communes;

d) a health resort fee ${ }^{3}$, which is collected for each commenced day of stay, from natural persons, staying for health, tourist, holiday, or training purposes in towns located in the areas, which have been granted the status of a health resort, under the provisions of the Act of 28 July 2005 on Health Resort Medical Care, Health Resorts, Health Resort Protection Areas and Health Resort Communes;

e) an advertising fee, which is collected for the installation of billboards.

The above list demonstrates that only the market fee, in addition to the advertising fee, may be directed also at entrepreneurs. It seems, therefore, that the communes which have a large potential, and, in particular, possess communication routes, may count on the increase of their revenues for the collection of those fees ${ }^{4}$.

The collection of an advertising fee is the final element of the whole process, which may succeed only where all statutory prerequisites are met. First,

\footnotetext{
${ }^{2}$ This fee is not collected from: staff of diplomatic missions and consular posts, persons with high degree of disability, within the meaning of the Act of 27 August 1997 on Vocational and Social Rehabilitation and Employment of Persons with Disabilities - for owning one dog; disabled persons, within the meaning of the Act of 27 August 1997 on Vocational and Social Rehabilitation and Employment of Persons with Disabilities - for owning an assistance dog; persons over 65 years of age running households on their own - for owning one dog; payers of agricultural tax on farm holdings - for owning not more than two dogs (Act on Taxes and Local Fees, 1991, Articles 18a and 19).

${ }^{3} \mathrm{~A}$ health resort fee is also a local fee and may be called a climate fee. The introduction of health resort fees excludes the collection of local fees, referred to in item c).

${ }^{4}$ Since the legislator explicitly uses the term „fee”, it seems justified not to use the term „tax" when referring to it. At the same time, it is beyond doubt that this fee has a fiscal nature. The classification of an advertising fee as a tax or fee is thoroughly discussed by Goleń in his commentary to Article 4 (Goleń, 2016, p. 68).
} 
a fee must be determined, and afterwards all subjective and objective requirements must be established for it to be deemed legitimate. At the same time, the legislator introduced a number of exemptions from the fee, as in the case of other local fees. A common denominator are the principles regulating the adoption of resolutions, and the competence of a municipal council to pass resolutions in this regard.

Pursuant to Article 17a(1) of the Act on Taxes and Local Fees, the municipal council may introduce an advertising fee on billboards or advertising devices. Thus, billboards and advertising devices determine the objective scope necessary to establish and collect a fee.

In accordance with Article 1(a)(3a) of the Act on Taxes and Local Fees, the terms used in the Act, such as: advertising, a billboard, an advertising device, a sign, mean, respectively, advertising, a billboard, an advertising device, a sign, within the meaning of the Act of 27 March 2003 on Spatial Planning and Management (Act on Spatial Planning and Management, 2003).

Advertising means propagating, in any visual form, information to promote persons, companies, goods, services, undertaking or social movements. This is a legal definition, although in the legal literature one may find a number of definitions of advertising ${ }^{6}$ and classifications made in relation to the criterion of legal regulation. But the propagation requires a "carrier" to be made public (to be expressed externally). A billboard or, to be more precise, its flat part (the board), which, together with construction elements and mounting elements, makes up a billboard, may be such a carrier. If, however, a given object, which is used to display an advertisement, has no flat board, then, within the meaning of the Act on Spatial Planning and Management, it becomes an advertising device. Both objects should be used for the display of products, services, etc., although they do not have to be displayed at a given time for the object to be called a billboard or an advertising device. In both cases the legislator reserved that billboards and advertising devices are not only objects on which advertising is displayed, but objects which are to serve this purpose.

\footnotetext{
${ }^{5}$ Compare also Article 2(16a)-(16d) of the Act on Spatial Planning and Management.

${ }^{6}$ In the legal literature there were different definitions of advertising. Thus, advertising is the expression which stimulates the increase of the sale of goods or services (Wiszniewska, Skubisz, 1992). Advertising is defined very broadly as the attempts aimed at popularization of or arousing interest in goods or services (Jaworska-Dębska, 1993). Whereas, Rączka, when defining advertising, draws attention to the need to distinguish legal notions such as: commercial information or offers within the meaning of the civil code (Rączka, 2012, pp. 38-42).
} 
Thus, advertising and its very essence, based on the concept of display, do not constitute a sine qua non condition in the definition of a billboard or an advertising device. For example, billboards include, in particular: advertising banners, advertisements placed on building windows, scaffolding, fences or construction site equipment. The examples presented expressis verbis are to prevent the attempts to evade the Act, where advertisements are placed on objects intended for other purposes. Thus, if a window pane is considered a board, then a window frame with all mounting elements constitutes, within the meaning of the legal definition referred to, a whole billboard. This is a definition within the meaning of tax regulations. Similarly, construction safety nets may constitute a board, whereas scaffolding, on which they are spread, are construction elements making up a billboard within the meaning of tax regulations.

Also those boards, on which advertisements are not displayed, also constitute billboards. All remains of billboards, i.e. bare structures and mounting elements, constituting only the framework and construction skeletons if they do not have a flat surface used to display advertisements, qualify as advertising devices. The introduction of an advertising fee for the possession of "dead billboards", should be perceived as positive, since it will force property owners to disassemble them in order to avoid paying the fee. Consequently, it may lead to clearing the space of empty and old boards, which spoil the spatial aesthetics. It seems that an empty billboard or an old board or structure do not have any aesthetic and informative value, which puts them in a worse light than an active board, on which an advertisement is displayed. (Obviously, it is difficult to make and justify certain structures based on subjective features related to aesthetic sensitivity; however, it seems justified to assume that, taking into account two situations, where the first one consists in to installing empty and ruined billboards by the side of the road, whereas the second one in installing active billboards, the latter is better, because advertisers want to reach the recipient, while maintaining positive visual feelings, also with regard to the aesthetics, forcing the owners of such carriers to maintain adequate standards.

The concept of a sign should also be noted, since it is a specific type of a billboard or an advertising device, for which no advertising fee is collected. It contains information on the activity conducted on the property, on which such a billboard or an advertising device is installed. It seems that the introduction of the exemption referred to effectively decreased the objective scope of the application of advertising fees. Owing to such a wide definition of a sign, in many cases it is impossible to effectively collect an advertising 
fee. Irrespective of whether the aim of the legislator was to improve the spatial aesthetics or enable the collection of advertising fees in order to increase the revenues of units, none of those aims will be achieved, due to the legal definition of a sign. However, a sign may constitute an advertisement, and the marring of walls, windows or shop windows by the names of chain stores and other goods distribution outlets may be exempted from the fee because an advertisement is displayed in the form of the sign.

In the case of freestanding and large surface buildings problematic are also pylons, which exert a lot of influence on the landscape and, which, literally speaking, fulfil the basic characteristics of a sign. It should be also remembered that a logo or a sign, installed on a pylon, may be also installed on the roof of a building if there is no space for installing a pole, and the building structure makes it possible for it to be installed there. If a seat of a given entrepreneur is located in the building, the company name displayed in a graphic form may be considered a sign. Then it constitutes a specific type of a sign, since the manner of display, including the lighting, makes it to be more than clearly noticed within the space (e.g. from a certain perspective it is seen as towering above a city, square, or alley). By introducing the exemption concerning a sign, the legislator deprived itself of the possibility of generating revenues from advertising fees.

Furthermore, an advertising fee is not collected for signs, as long as they comply with the terms and conditions regarding the installation of small architecture structures, billboards, advertising boards and fences. To the contrary, the legislator allows the collection of an advertising fee if a sign is installed in contradiction to the applicable conditions. Firstly, it should be established how to assess a situation, how to assess if a sign has been installed properly, where such conditions are missing or, where the conditions determined in a spatial development plan are very general. Should one assume the principle of construction freedom, based on constitutionally protected property right, then all doubts in this regard should be considered to the benefit of an owner, that is as the exemption from the payment. It cannot be also ruled out that, in relation to signs, a municipal council will be forced to amend spatial development plans in this regard, which may pose a risk of an obligation to pay a rezoning fee.

The remaining exceptions related to exemptions from advertising fees are provided for in Article $17 \mathrm{a}(5)(1)$ of the Act on Taxes and Local Fees. Pursuant to the above-mentioned provision, an advertising fee is not collected if billboards or advertising devices are not visible from areas available to the public. In particular, this provision may be related to advertisements displayed in 
enclosed areas, cooperative housing estates, etc. Furthermore, it seems that this provision cannot be understood literally (that it is about the visibility of the device itself), but it should be interpreted broadly in such a way that it is about the visibility of the content, which this device may display.

Moreover, an advertising fee is not collected if an advertising device or a billboard is used solely for dissemination of religious information, related to the activities of churches or religious associations, if a billboard or an advertising device is located within the areas used as places of worship and religious activity as well as cemeteries or places commemorating persons, institutions or events. Permanent commemoration of persons or institutions, as provided for by Article 17(a)(5)(4)(a) of the Act on Taxes and Local Fees, should be indicated by the fact that a certain object is not used in any manner to present other content, encouraging people to purchase a product or use a service. From the perspective of the content displayed it is not a billboard, since the essence of the message has no commercial context. Therefore, if a billboard only for certain periods, e.g. for 2 months when a given institution is organizing a historical event, is used to commemorate the anniversary of a historical event, then an advertising fee should be collected throughout the whole period. It is obvious that it may be difficult to draw a line between permanency and periodicity difficult, as the notion of permanency has not been defined precisely.

Nonetheless, determination by an authority when, at what time of the year, and for what purposes, a given billboard was used, including determination in which periods it advertised commercial products, and in which - events, seems to be a task, the costs of which may exceed the amount of advertising fees. Thus, a permanent display is a display which is focused only on one object, subject to exemption. A municipal council may introduce other exemptions of an objective nature. This is directly provided for by Article 19(3) of the Act on Taxes and Local Fees.

The subjective scope comprises 4 categories of persons bound to pay advertising fees. They include: an owner (a co-owner), a perpetual usufructuary (which excludes owner's liability, and the owner is, after all, the state treasury or a local government unit), an owner-like possessor of state and private properties, and a dependent possessor of state properties. (It should be noted that Article 17(3)(4) of the Act on Taxes and Local Fees provides a basis for distinguishing the situation of a dependent possessor of property, structures or their parts, which constitute state and private property).

A fee is collected from an "administrator" (who is not always an owner) of property, on which a billboard or an advertising device, used for display 
of promoting materials, has been installed, irrespective of whether they are displayed or not. In the literature it is argued that in the case of advertising displayed by an owner-like possessor, the owner is not a tax payer and there is no joint and several fiscal liability in this regard (Goleń, 2016, p. 78; Judgment of the Constitutional Tribunal, 1995). This issue seems to be more complex at least because possession is a state, which may cease quite quickly, and the advertisement may remain in place, with the owner still showing no interest in the property.

It may be particularly difficult to determine a fee in the case of unconventional billboards and advertising devices. The fee amount is a total of the value of its constant part and variable part, the amounts of which are determined by a resolution, under Article 19 of the Act on Taxes and Local Fees. The provision referred to constitutes a basis for adopting a resolution for all types of local fees. The constant part is a flat fee, regardless of the surface area of a billboard or an advertising device, used for displaying advertisements. The variable part depends on the size of the surface area of a billboard or an advertising device, used for displaying advertisements.

As has been mentioned before, billboards, where the surface area of an advertisement is not standard, due to protruding display elements, may pose difficulties. Technological possibilities and creativity of marketing teams give rise to the assumption that not in every case the surface area will be calculated by simply multiplying the length of the sides inscribed in the rectangle of a billboard. Billboards may be equipped, for example, with lamps emitting a beam of light, not directed at the recipient, which correspond graphically to the advertisement, thus visually expanding the surface area of the display. Other elements, such as inflatable balls, balloons, flags, etc., which will appear at billboards only periodically, or pulsating elements, may also be used. Such elements do not have to be attached to the billboard itself; furthermore, they do not present any text content themselves. Nonetheless, in combination with the text displayed on the billboard they may constitute a single composition? ${ }^{7}$.

It ensues from Article 17b(4) of the Act on Taxes and Local Fees that irregular surface areas are calculated by „encompassing” display surface areas by a rectangular prism, whose surface constitutes the basis for making

\footnotetext{
${ }^{7}$ For example, an advertisement of a new device, which may be purchased at a discount price on the anniversary of a store chain, placed on a billboard, may be accompanied by balloons attached to the billboard structure. In such a case, the protruding advertisement gains a new, larger dimension.
} 
calculations. The fee depends on the lateral surface area of a rectangular prism inscribed in the advertising device (Stelmaszczyk, 2016).

The fact that the legislator made a reservation that fees may be collected only in the areas, where terms and conditions regarding installation of small architecture structures are applicable, does not mean that, without applying those terms and conditions, a resolution on advertising fees within a commune cannot be adopted. A resolution of a municipal council, determining the manner of making declarations, fee rates, type of potential exemptions, deadlines for and manner of paying advertising fees, may be applicable within one commune, also where there are no terms and conditions regulating the installation of advertising devices. In this regard, communes should prepare possible adjustable changes, directed at harmonisation of installation standards within the area of advertising devices, but such changes may be implemented for certain commune areas without affecting the validity of a resolution on an advertising fee. If the terms and conditions are applied only to certain commune areas, as regards the installation of billboards, it will not be possible to collect fees in the areas not regulated in this regard.

A resolution on terms and conditions of the installation of billboards and advertising devices is adopted under Article 37a of the Act on Spatial Planning and Management. It may constitute a separate resolution, but the adoption of a resolution on the amendment of a spatial plan, if the subject of the plan is related to the issues indicated, should be allowed. In the context of procedural issues, as in the case of local plans, the procedure commences with the adoption of a resolution of intent and ends with the adoption of a resolution determining such terms and conditions.

The indicated sources of revenues for local government units will be supported by additional money from fines for the failure to pay fees and by collection costs and interest on the fees not paid within deadlines. Fines are imposed by a competent commune executive authority, by way of an administrative decision, for the failure to notify the installation or defective installation of billboards and advertising devices.

The amount of a fine is determined as a product of the surface area of a billboard or an advertising device, used to display an advertisement, expressed in square metres and 40 times the variable part of an advertising fee adopted by a municipal council.

\footnotetext{
${ }^{8}$ In the meantime the commune head, mayor or president of the city prepares a draft and obtains proper opinions and arrangements for the drafts of a future resolution.
} 
Two types of decisions issued in this matter can be distinguished. The former concern the determination of a fine for the period from the commencement of the proceedings to the issuance of a decision ${ }^{9}$. The latter concern a fine for the period from the issuance of the first decision to the removal or adaptation of a billboard or an advertising device to legal requirements. An obligation to adapt or remove a billboard or an advertising device is imposed with the first decision and is immediately enforceable, but the time necessary to fulfil the obligation may be different, including the application of non-monetary debt collection means such as substitutive performance. The costs of substitutive performance will be, obviously, collected like possible unpaid fines by the application of monetary debt collection means. Thus, the period for the fulfilment of the obligation to remove a billboard depends directly on the behaviour of a person, who this obligation was imposed on. Following disassembly or adaptation of an advertising device or a billboard, the commune head, mayor or president of the city, being aware of the period which passed from the issuance of the first decision in this matter, may issue another decision, taking into consideration the period which passed from the fulfilment of the obligation.

Collecting fees on so-called „empty billboards” may, in practice, force their disassembly, which will have a positive influence on the landscape. Considering windows, shop windows, facades or even building structures as advertising devices or billboards is certainly not aimed at making them to be used only for their intended purposes. Thus, it seems that the legislator is not against the sheer idea of using windows or facades for placing advertisements, but only wishes to facilitate the collection of fees in this regard. From this perspective, the introduction of exemptions from fees, as regards the installation of signs, partly thwarts the economic goal of the introduction of the aforementioned fees. Furthermore, the collection of fees itself is dependent on the fulfilment of a number of conditions, including the introduction of tax resolutions and the amendment of planning resolutions. This, in turn, poses a risk of damages claims related to the reduction of revenues for the lease of the surface area of buildings and building structures.

\footnotetext{
${ }^{9}$ They do not include the period from before the commencement of the proceedings, that is the period when the advertisement was undoubtedly there.
} 


\section{References}

Act on Health Resort Medical Care, Health Resorts, Health Resort Protection Areas and Health Resort Communes (2005). Journal of Laws (167/1399). Warszawa: Prime Minister of Poland.

Act on Spatial Planning and Management (2003). Journal of Laws (2015/199, 443, 774). Warszawa: Prime Minister of Poland.

Act on Taxes and Local Fees (1991). Journal of Laws (2014/849). Warszawa: Prime Minister of Poland.

Borszowski P., \& Stelmaszczyk K. (2016). Ustawa o podatkach i opłatach lokaInych. Komentarz Lex. Warszawa: Wolters Kluwer.

Goleń G., Fogel A. (Eds.), Staniewska, A. (2016). Ustawa krajobrazowa. Warszawa: Wolters Kluwer.

Jaworska-Dębska B. (1993). Wokół pojęcia reklamy, Warszawa: Przegląd Ustawodawstwa Gospodarczego, No. 12.

Małecka-Łyszak M. (2011). Problematyka reklam na gruncie regulacji prawnych, [In:] J. Koczanowski (Ed.), Działalność reklamowa, wybrane aspekty publicznoprawne, Bydgoszcz-Kraków: OW Branta.

Orżewski W. (2012). Reklama - aspekty prawne. Poznań: PWP Juris.

Rączka G. (2012). Definicja reklamy, [In:] A. Namysłowska (Ed.), Reklama aspekty prawne. pp. 35-36. Warszawa: Wolters Kluwer.

Wiszniewska I., Skubisz R. (1992). Środki zapobiegania nieuczciwej reklamie w projekcie ustawy o zwalczaniu nieuczciwej konkurencji, Państwo i Prawo, Nr 4. 